\title{
Parent Story Telling Skill at Baitul Maqdis Cipta Edukasi
}

\section{Kemampuan Mendongeng di Baitul Maqdis Cipta Edukasi}

\author{
Uha Julaeha $^{1}$, Prijana $^{2}$, Andri Yanto ${ }^{3}$ \\ Prodi Ilmu Perpustakaan Universitas Padjadjaran 1,2,3
}

Paper Type:

Research Paper

Submitted 25 April 2019 Accepted 22 Desember 2019

Abstract

Background of the study: informal education can be enhanced by providing parents with parenting education (non-formal education for parents) which can be obtained through courses, training, study groups, and community learning centers in order to support lifelong education. One of them is through inspiring fairy tale training for parents and educators organized by the educational institution Baitul Maqdis Cipta Edukasi (BMCE).

Purpose: This research aims to determine the differences in the ability of storytelling participants between before and after being given treatment in the form of storytelling training in Baitul Maqdis Cipta Edukasi.

Method: The method in this research uses a quantitative method through a pre-experimental study approach with the form of one group pretest-posttest design. The research population consisted of 36 Baitul Maqdis Cipta Edukasi storytelling trainees. Sampling is based on the proportion of total sampling, which is a total of 36 participants. The research data was collected using primary data and secondary data. Primary data in the form of questionnaires, observation, interviews. Secondary data in the form of library studies. The research data uses a nominal scale and analyzed using a sign test (sign test) with a $95 \%$ confidence level.

Findings: The results of this study indicate that there are differences in storytelling skills in the form of the ability to understand and choose story material, the ability to tell fairy tales, and the ability to tell messages behind fairy tales after being given treatment.

Conclusion: So that storytelling training improves the ability of storytelling participants and there are differences in the form of additional knowledge and skill of participants.

Keywords: Training, Fairy Tale, Storytelling Skill, Andragogy, Parent 


\begin{abstract}
Abstrak
Latar Belakang Masalah: Pendidikan informal anak dapat ditingkatkan salah satunya dengan membekali orang tua melalui pendidikan parenting (pendidikan nonformal orang tua) yang bisa diperoleh melalui kursus, pelatihan, kelompok belajar, dan pusat kegiatan belajar masyarakat dalam rangka mendukung pendidikan sepanjang hayat. Salah satunya melalui pelatihan dongeng inspiratif untuk orang tua dan pendidik yang diselenggarakan oleh lembaga edukasi Baitul Maqdis Cipta Edukasi (BMCE).

Tujuan: Penelitian ini bertujuan untuk mengetahui perbedaan kemampuan mendongeng peserta antara sebelum dan sesudah diberikan treatment berupa pelatihan storytelling di Baitul Maqdis Cipta Edukasi.

Metode Metode penelitian ini menggunakan metode kuantitatif dengan pendekatan studi pra-eksperimen dalam bentuk one group pretest-posttest design. Populasi penelitian ini terdiri dari para peserta pelatihan storytelling Baitul Maqdis Cipta Edukasi sebanyak 36 orang. Pengambilan sampel berdasarkan total sampling yaitu sejumlah keseluruhan peserta yang hadir sebanyak 36 peserta. Data penelitian dikumpulkan menggunakan data primer dan data sekunder. Data primer berupa angket / kuesioner, observasi, serta wawancara. Data skunder berupa studi kepustakaan. Data penelitian menggunakan skala nominal dan dianalisis menggunakan uji tanda (sign test) dengan derajat kepercayaan $95 \%$.

Temuan Hasil dari penelitian ini menunjukkan bahwa terdapat perbedaan kemampuan mendongeng berupa kemampuan memahami dan memilih bahan cerita, kemampuan menuturkan dongeng, dan kemampuan menuturkan pesan dibalik narasi dongeng setelah diberikan treatment.

Simpulan Sehingga pelatihan storytelling dapat meningkatkan kemampuan mendongeng peserta dan terdapat perbedaan berupa penambahan pengetahuan dan kemampuan peserta.
\end{abstract}

Kata Kunci: Pelatihan, Dongeng, Storytelling, Andragogi.

To cite this document:

Uha Julaeha, (2019), Parent Storytelling Skill at Baitul Maqdis Cipta Edukasi, Record

and Library Journal, 5(2), 160-175

Open access under Creative Commons Attribution-Non Commercial-Share A like 4.0 International Licence

(CC-BY-SA) 


\section{Pendahuluan}

Pendidikan turut andil dalam menampilkan wajah peradaban sebuah negara dan menjadi indikator maju atau tidaknya negara tersebut. Menurut Undang-Undang Nomor 20 tentang Sistem Pendidikan Nasional (Sisdiknas) Tahun 2003 menjelaskan bahwa pendidikan adalah usaha sadar dan terencana untuk mewujudkan suasana belajar dan proses pembelajaran agar peserta didik secara aktif mengembangkan potensi dirinya untuk memiliki kekuatan spiritual keagamaan, pengendalian diri, kepribadian, kecerdasan, akhlak mulia, serta keterampilan yang diperlukan dirinya, masyarakat, bangsa, dan negara. Adapun upaya pemerintah meningkatkan kualitas pendidikan ialah melalui berbagai kebijakan diantaranya melalui sertifikasi guru dan dosen, bantuan operasional sekolah, pemberian block grant, menetapkan standar nasional yang dituangkan dalam PP No. 19 tahun 2005 tentang Stand ar Nasional Pendidikan, serta mengalokasikan anggaran APBN sebesar 20\% (Raharjo, 2012).

Dukungan berbagai macam kebijakan maupun alokasi dana APBN pemerintah untuk pendidikan ternyata belum mampu membuat mutu pendidikan Indonesia berad a diperingkat tiga besar negara-negara di ASEAN. Hal ini dilihat berdasarkan laporan Program of International Student Assessment (PISA) tahun 2015 yang diselenggarakan oleh OECD. Indonesia menempati peringkat 64 dari 72 negara anggota (peringkat 7 dari bawah) untuk kategori membaca. Dengan peringkat tersebut, Indonesia tertinggal dari tiga negara tetangga ASEAN yaitu Singapura (peringkat 1), Vietnam (peringkat 29), dan Thailand (peringkat 57). Hal tersebut terjadi salah satunya karena faktor Indonesia masih memiliki permasalahan pada mutu pendidikan, kurikulum yang sering berubah, sarana dan prasarana pendidikan kurang merata, serta setiap daerah memiliki kualitas berbeda-beda dalam menyeleksi guru yang secara langsung mempengaruhi kualitas dalam mengajar. Terlebih lagi pendidikan di Indonesia masih minim dalam penguatan karakter peserta didik. Padahal pendidikan karakter sama-sama memiliki pengaruh terhadap kualitas pendidikan Indonesia. Karena di dalam pendidikan, terdapat pula proses pembentukan karakter selain pembentukan literasi pada setiap anak didik.

Perbaikan pemerintah untuk mutu pendidikan Indonesia salah satunya dengan mengadakan penguatan karakter pada pendidikan yang tertuang dalam Peraturan Presiden Nomor 87 Tahun 2017 tentang Penguatan Pendidikan Karakter (PPK). PPK merupakan gerakan pendidikan di bawah tanggungjawab satuan pendidikan untuk memperkuat karakter peserta didik melalui harmonisasi olah hati, olah rasa, olah pikir, dan olah raga dengan pelibatan dan kerja sama antara satuan pendidikan, keluarga, dan masyarakat sebagai bagian dari Gerakan Nasional Revolusi Mental (GNRM). Pada satuan pendidikan formal, guru biasanya membaurkan nilai-nilai karakter dalam kegiatan belajar mengajar, sedangkan di tingkat keluarga ataupun satuan pendidikan non formal kegiatan penguatan karakter dapat dimaksimalkan dengan berbagai aktivitas literasi.

Bentuk pendidikan informal anak dalam aktivitas literasi dapat berupa menghabiskan quality time bersama keluarga ataupun melibatkan komunitas-komunitas literasi yang ada di lingkungan keluarga ataupun masyarakat sekitar. Misalnya dengan menonton bersama, makan bersama, membaca bersama, maupun interaksi yang dibangun antara keduanya (orang tua dan anak). Pendidikan informal anak dapat ditingkatkan salah satunya dengan membekali orang tua melalui pendidikan parenting (pendidikan nonformal orang tua) yang bisa diperoleh melalui kursus, pelatihan, kelompok belajar, dan pusat kegiatan belajar masyarakat dalam rangka mendukung pendidikan sepanjang hayat. Salah satunya melalui pelatihan dongeng inspiratif untuk orang tua dan pendidik yang diselenggarakan oleh lembaga edukasi Baitul Maqdis Cipta Edukasi (BMCE).

Dongeng menjadi media yang paling sesuai untuk mendidik anak-anak. Hal ini disebabkan selain karena berkonten ringan, aktivitas dalam dongeng membuat anak dapat berimajinasi dengan bebas versi mereka sendiri tanpa didikte orang lain. Dongeng juga menuntut interaksi dua arah antara pendongeng dan audiensi. Julaeha (2016) menyebutkan bahwa banyak manfaat dari dongeng seperti kemandirian, rasa kepercayadirian, kepekaan sosio-emosional, dan lain-lain yang dapat diatur dengan sengaja dalam dongeng agar dapat ditiru oleh anak-anak. Dongeng mengajak anak untuk gemar baca. To cite this document:

Uha Julaeha, (2019), Parent Storytelling Skill at Baitul Maqdis Cipta Edukasi, Record

and Library Journal, 5(2), 160-175

Open access under Creative Commons Attribution-Non Commercial-Share A like 4.0 International Licence

(CC-BY-SA) (c) (i) (2) 
Dongeng juga dapat meningkatkan kemampuan literal anak. Lebih lanjut Malo dan Bullard (2000) menyatakan bahwa "As with parents, encouraging storytelling can assist the child in seeing the link between school and home as well as providing important literacy skills." Untuk itu perlu adanya peningkatan kemampuan storytelling para orangtua untuk meningkatkan kemampuan literasi.

Menurut Frude and Killick (2011) menyatakan "attachment theory suggests that storytelling by a key attachment figure is especially powerful, and that storytelling may strengthen attachment relationships in important ways." Pada teori attachment menyarankan bahwa orangtua sebagai figur kunci dalam kegiatan storytelling dan melalui storytelling pula dapat meningkatkan hubungan antara orang tua dengan anak. Salah satu yang menjadi latar belakang mengapa orang tua menjadi aktor kunci dalam peningkatan literasi bagi putra putri mereka karena pemahaman dan kemampuan orang tua terkait storytelling belum sepenuhnya optimal serta orang tua tidak memiliki waktu untuk melakukan aktivitas storytelling di rumah. Seperti survei yang dilakukan oleh TalkTalk Group tahun 2011 yang menyatakan bahwa "parents lead such busylives that they no longer have time to read bedtime stories to their children" (Oduolowu \& Oluwakemi, 2014).

Berbagai manfaat dari storytelling yang dilakukan oleh orang tua, seperti yang dinyatakan oleh Sund ari (2016) bahwa "mend ongeng (storytelling) yang kerap dilakukan orang tua di rumah, maupun guru di sekolah diyakini efektif mendorong kemajuan bahasa dan literasi, logika, serta berpikir kritis anak" (Sundari, 2016). Hal ini juga diungkapkan oleh Wardiah (2017), Ayuni, Siswati, dan Rumawati (2013) bahwa storytelling merupakan salah satu cara yang efektif untuk mengembangkan aspekaspek kognitif (pengetahuan), afektif (perasaan), sosial, dan aspek konatif (penghayatan) anak-anak serta meningkatkan empati anak. Sedangkan menurut Padila, Agusramon dan Yera (2019) menyatakan bahwa "manfaat dari kegiatan mendongeng antara lain: mengembangkan fantasi, empati dan berbagai jenis perasaan lain, menumbuhkan minat baca, membangun kedekatan dan keharmonisan, media pembelajaran."

Terdapat dua teknik dalam mendongeng, yaitu mendongeng dengan teks atau membacakan cerita (storyreading) dan mendongeng tanpa teks atau bertutur (storytelling). Pelatihan dongeng inspiratif di Baitul Maqdis Cipta Edukasi menggunakan teknik mendongeng bertutur (tanpa teks) atau storytelling. Storytelling yang dikemas dalam bentuk pelatihan memungkinkan adanya praktek langsung yang diarahkan oleh pelatih mengenai teknik-teknik mendongeng yang komunikatif. Peserta juga dapat menanyakan perihal permasalahan yang sedang terjadi pada anak mereka untuk menemukan solusinya. Selain itu, pelatihan memungkinkan adanya interaksi antara peserta dimana peserta dapat saling bertukar pengalaman. Sehingga, interaksi dalam pelatihan tersebut dapat memperkaya kemampuan mendongeng orang tua.

Berdasarkan latar belakang yang telah dijelaskan tersebut, serta dari studi pustaka yang telah didapat oleh penulis, dapat dinyatakan bahwa belum ada kajian yang fokus terhadap hasil pelatihan storytelling bagi orang tua melalui pendekatan praktisi dongeng, apakah pelatihan mendongeng yang diberikan terhadap orang tua memberikan perubahan dan manfaat dalam peningkatan kemampuannya. Dengan demikian, belum diketahui "apakah terdapat perbedaan kemampuan mendongeng orang tua setelah menerima pelatihan storytelling di Baitul Maqdis Cipta Edukasi?"

Tujuan penelitian tersebut adalah untuk mengetahui perbedaan kemampuan mendongeng peserta antara sebelum dan sesudah menerima pelatihan storytelling berupa kemampuan memahami dan memilih bahan cerita, kemampuan menuturkan dongeng, dan kemampuan menuturkan pesan dibalik narasi dongeng. Adapun hipotesis dalam penelitian ini adalah $\mathrm{H}_{0}$ : kemampuan mendongeng peserta sebelum pelatihan storytelling di Baitul Maqdis Cipta Edukasi tidak memiliki hubungan signifikan terhadap kemampuan mendongeng peserta setelah pelatihan storytelling di Baitul Maqdis Cipta Edukasi. $\mathrm{H}_{1}$ : kemampuan mendongeng peserta sebelum pelatihan storytelling di Baitul Maqdis Cipta Edukasi memiliki hubungan signifikan terhadap kemampuan mendongeng peserta setelah pelatihan storytelling di Baitul Maqdis Cipta Edukasi.

Hasil penelitian ini diharapkan menjadi salah satu pendekatan yang digunakan dalam mendidik anak, serta diharapkan dapat bermanfaat dalam mengembangkan ilmu pengetahuan, khususnya

To cite this document:

Uha Julaeha, (2019), Parent Storytelling Skill at Baitul Maqdis Cipta Edukasi, Record

and Library Journal, 5(2), 160-175

Open access under Creative Commons Attribution-Non Commercial-Share A like 4.0 International Licence

(CC-BY-SA)

$$
\text { (c) (i) (2) }
$$


bidang Ilmu Informasi dan Perpustakaan mengenai pelatihan storytelling untuk meningkatkan minat baca anak melalui metode mendongeng dari orang tua atau pendidik.

\section{Metode Penelitian}

Penelitian ini merupakan penelitian kuantitatif dengan menggunakan pendekatan studi praeksperimen berbentuk one group pretest-posttest design. Pra-eksperimen merupakan penelitian eksperimen dengan mengamati satu kelompok saja dan melakukan intervensi (Creswell, 2010 dalam Prijana, Winoto, Yanto, 2017). Desain pra-eksperimen dalam penelitian ini berbentuk one group pretest-posttest design dimana menggunakan satu kelompok subjek tanpa diberlakukan kelas kontrol, karena pengujian penelitian dilihat dari perbandingan hasil pretest dan posttest penelitian. Pretest (O1) adalah observasi yang dilakukan sebelum eksperimen. Sedangkan posttest $(\mathrm{O} 2)$ adalah observasi yang dilakukan setelah eksperimen (Agustin, 2017). Perbedaan antara O1 dan O2 diasumsikan sebagai efek perlakuan (treatment) dari eksperimen.

Gambar 1. One Group Pretest-Posttest Design (Christensen, 2007)

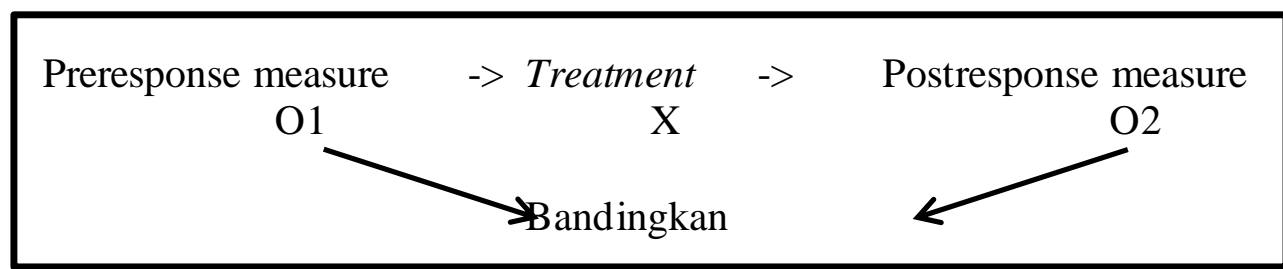

Objek penelitian ini adalah peserta pelatihan storytelling di Baitul Maqdis Cipta Edukasi. Pemilihan peserta pada penelitian ini merepresentasikan orang dewasa yang terlibat dan dapat mempengaruhi pendidikan informal anak. Undang-undang sendiri berbeda-beda dalam mengkategorikan usia dewasa. UU Nomor 1 Tahun 1974 tentang Perkawinan dalam Pasal 47 ayat (1) mengkategorikan usia yang termasuk kedalam orang dewasa adalah warga negara yang telah mencapai usia 18 tahun atau yang sudah menikah. Sementara ketentuan dalam UU Hukum Perdata Pasal 330 menyatakan bahwa seseorang dianggap sudah dewasa jika sudah berusia 21 tahun atau sudah (pernah) menikah. Populasi penelitian ini adalah peserta pelatihan storytelling sebanyak 36 orang. Teknik yang digunakan ialah teknik sampling jenuh yaitu teknik penentuan sampel yang melibatkan semua anggota populasi.

Jenis data dalam penelitian ini menggunakan data primer dan sekunder. Data primer berupa kuisioner, wawancara, dan observasi. Data sekunder berasal dari buku, jurnal, laporan penelitian terdahulu, dan sumber-sumber lainnya. Penelitian ini menggunakan skala nominal dengan metode analisis sumber data menggunakan uji tanda (sign test). Uji tanda dapat digunakan pada skala pengukuran dari variabel penelitian berbentuk nominal dengan tanda perubahan (+/-) (Rihandoyo, 2009). Uji tanda juga dipergunakan untuk menguji perbedaan ranking (median selisih skor/ranking) dua buah populasi berdasarkan ranking (median selisih skor/ranking) dua sampel berpasangan (Andriani, 2014).

\section{Hasil dan Diskusi}

Berikut ini adalah deskriptif responden dari hasil penelitian yang telah diolah. Peneliti mengumpulkan data primer pada peserta pelatihan storytelling untuk mengetahui perbedaan antara sebelum dengan sesudah pelatihan pada kemampuan mendongeng dengan menguji 36 peserta dari berbagai golongan masyarakat. Pada analisis statistik deskriptif, peneliti akan menyajikan tabel tunggal dan menjabarkannya. Data ini dibutuhkan untuk melihat latar belakang responden yang akan diuji sebelum dan sesudah mereka diberikan treatment berupa pelatihan storytelling oleh peneliti.

To cite this document:

Uha Julaeha, (2019), Parent Storytelling Skill at Baitul Maqdis Cipta Edukasi, Record

and Library Journal, 5(2), 160-175

Open access under Creative Commons Attribution-Non Commercial-Share A like 4.0 International Licence

(CC-BY-SA)

$$
\text { (c) (i) (2) }
$$


Tabel 1 Ketertarikan Mendongeng Responden

\begin{tabular}{lll} 
Ketertarikan Mendongeng & $\mathrm{F}$ & $\%$ \\
\hline Ya & 36 & $100 \%$ \\
Tidak & 0 & $0 \%$ \\
Total & 36 & $100 \%$ \\
\hline
\end{tabular}

Berdasarkan tabel di atas, diketahui bahwa responden yang tertarik mend ongeng sebanyak 36 $(100 \%)$ sedangkan yang tidak tertarik sebanyak 0 orang $(0 \%)$. Sehingga hasil persentase tersebut dapat dikatakan bahwa $100 \%$ responden tertarik dengan mendongeng.

Tabel 2 Sumber Pencarian Bahan Cerita

\begin{tabular}{lll} 
Media & $\mathrm{F}$ & $\%$ \\
\hline Browsing di internet & 14 & $39 \%$ \\
Perpustakaan & 10 & $28 \%$ \\
Koleksi Pribadi & 9 & $25 \%$ \\
Forum/Komunitas & 3 & $8 \%$ \\
Total & 36 & $100 \%$ \\
\hline
\end{tabular}

Berdasarkan tabel tersebut, diketahui bahwa responden yang sering mencari bahan cerita melalui browsing internet sebanyak 14 orang (39\%), mencari di perpustakaan sebanyak 10 orang (28\%), memiliki buku cerita koleksi pribadi sebanyak 9 orang (25\%), sedangkan mencari bahan cerita di forum atau komunitas sebanyak 3 orang (8\%). Sehingga hasil persentase tersebut dapat dikatakan bahwa responden lebih banyak mencari bahan cerita mendongeng melalui browsing internet.

Tabel 3 Keikutsertaan Pelatihan Storytelling Sebelumnya

\begin{tabular}{lll} 
Pelatihan & $\mathrm{f}$ & $\%$ \\
\hline Belum Pernah & 25 & $69 \%$ \\
Pernah & 11 & $31 \%$ \\
Total & 36 & $100 \%$ \\
\hline
\end{tabular}

Berdasarkan tabel tersebut, diketahui bahwa responden yang belum pernah mengikuti pelatihan storytelling sebanyak 25 orang (69\%) sedangkan yang sudah pernah mengikuti pelatihan storytelling sebanyak 11 orang $(31 \%)$. Sehingga hasil persentase tersebut dapat dikatakan bahwa responden lebih banyak yang belum pernah mengikuti pelatihan storytelling.

Tabel 4 Kemampuan Mencari Bahan Dongeng

\begin{tabular}{lllllll}
\hline \multirow{2}{*}{ Mampu } & Pretest & \multicolumn{3}{c}{ Posttest } & \multicolumn{3}{c}{ Selisih } \\
& $\mathrm{F}$ & $\%$ & $\mathrm{~F}$ & $\%$ & $\mathrm{f}$ & $\%$ \\
\hline Ya & 23 & $64 \%$ & 34 & $94 \%$ & 11 & \multirow{2}{*}{$30 \%$} \\
Tidak & 13 & $36 \%$ & 2 & $6 \%$ & & \\
Total & 36 & $100 \%$ & 36 & $100 \%$ & & \\
\hline
\end{tabular}

Berdasarkan tabel tersebut, diketahui bahwa responden yang memilih jawaban "ya" pada soal pretest, sebelum diberikan treatment pelatihan storytelling, berupa "anda dapat mencari bahan untuk dongeng sesuai dengan usia anak" sebanyak 23 orang (64\%) dan yang memilih jawaban "tidak" sebanyak 13 orang (36\%). Sedangkan responden yang memilih jawaban "ya" pada soal posttest,

To cite this document:

Uha Julaeha, (2019), Parent Storytelling Skill at Baitul Maqdis Cipta Edukasi, Record

and Library Journal, 5(2), 160-175

Open access under Creative Commons Attribution-Non Commercial-Share A like 4.0 International Licence

(CC-BY-SA)

(c) (1) (2) 
setelah diberikan treatment pelatihan storytelling sebanyak 34 orang $(94 \%)$ dan yang memilih jawaban "tidak" sebanyak 2 orang $(6 \%)$.

Hal tersebut menunjukkan adanya peningkatan setelah diberikan treatment pelatihan storytelling. Dilihat dari ad anya peningkatan jumlah yang menyatakan "ya" dan berkurangnya jumlah responden yang menyatakan "tidak" setelah diberikan metode storytelling, yaitu sebanyak 11 orang $(30 \%)$.

Tabel 5 Kemampuan Menyeleksi Bahan Cerita

\begin{tabular}{lllllll}
\hline \multirow{2}{*}{ Mampu } & \multicolumn{2}{l}{ Pretest } & \multicolumn{3}{l}{ Posttest } & Selisih \\
& $\mathrm{F}$ & $\%$ & $\mathrm{~F}$ & $\%$ & $\mathrm{f}$ & $\%$ \\
\hline Ya & 27 & $75 \%$ & 33 & $94 \%$ & \multirow{2}{*}{6} & \multirow{2}{*}{$19 \%$} \\
Tidak & 9 & $25 \%$ & 3 & $6 \%$ & & \\
Total & 36 & $100 \%$ & 36 & $100 \%$ & & \\
\hline
\end{tabular}

Berdasarkan tabel tersebut, diketahui bahwa responden yang memilih jawaban "ya" pada soal pretest, sebelum diberikan treatment pelatihan storytelling, berupa "anda menyeleksi bahan cerita sesuai dengan usia perkembangan anak" sebanyak 27 orang (75\%) dan yang memilih jawaban "tidak" sebanyak 9 orang (25\%). Sedangkan responden yang memilih jawaban "ya" pada soal posttest, setelah diberikan treatment pelatihan storytelling sebanyak 33 orang (94\%) dan yang memilih jawaban "tidak" sebanyak 3 orang $(6 \%)$.

Hal tersebut menunjukkan adanya peningkatan setelah diberikan treatment pelatihan storytelling . Dilihat dari adanya peningkatan jumlah yang menyatakan "ya" dan berkurangnya jumlah responden yang menyatakan "tidak" setelah diberikan metode storytelling, yaitu sebanyak 6 orang (19\%).

Tabel 6 Kemampuan Menentukan Bahan Cerita yang Dimiliki

\begin{tabular}{lllllll}
\hline \multirow{2}{*}{ Mampu } & \multicolumn{2}{l}{ Pretest } & \multicolumn{3}{l}{ Posttest } & Selisih \\
& $\mathrm{f}$ & $\%$ & $\mathrm{~F}$ & $\%$ & $\mathrm{f}$ & $\%$ \\
\hline Ya & 23 & $64 \%$ & 34 & $94 \%$ & \multirow{2}{*}{11} & $30 \%$ \\
Tidak & 13 & $36 \%$ & 2 & $6 \%$ & & \\
Total & 36 & $100 \%$ & 36 & $100 \%$ & & \\
\hline
\end{tabular}

Berdasarkan tabel tersebut, diketahui bahwa responden yang memilih jawaban "ya" pada soal pretest, sebelum diberikan treatment pelatihan storytelling, berupa "anda dapat menentukan bahan cerita yang dimiliki" sebanyak 23 orang (64\%) dan yang memilih jawaban "tidak" sebanyak 13 orang $(36 \%)$. Sedangkan responden yang memilih jawaban "ya" pada soal posttest, setelah diberikan treatment pelatihan storytelling sebanyak 34 orang (94\%) dan yang memilih jawaban "tidak" sebanyak 2 orang $(6 \%)$.

Hal tersebut menunjukkan adanya peningkatan setelah diberikan treatment pelatihan storytelling. Dilihat dari adanya peningkatan jumlah yang menyatakan "ya" dan berkurangnya jumlah responden yang menyatakan "tidak" setelah diberikan metode storytelling, yaitu sebanyak 11 orang $(30 \%)$.

Tabel 7 Peningkatan Kemampuan Memilih Bahan Cerita Dongeng

\begin{tabular}{lll}
\hline Sub Kemampuan & Selisih & \\
& $\mathrm{f}$ & $\%$ \\
\hline Mencari Bahan Cerita & 11 & $30 \%$ \\
Menyeleksi Bahan Cerita & 6 & $19 \%$ \\
Menentukan Bahan Cerita & 11 & $30 \%$ \\
Peningkatan & 9 & $26 \%$ \\
\hline
\end{tabular}

Berdasarkan hasil dari ketiga kuisioner tersebut, dapat disimpulkan bahwa terd apat peningkatan kemampuan dalam memilih bahan cerita dongeng setelah diberikan treatment pelatihan mendongeng yaitu sebanyak 9 orang $(26 \%)$.

To cite this document:

Uha Julaeha, (2019), Parent Storytelling Skill at Baitul Maqdis Cipta Edukasi, Record

and Library Journal, 5(2), 160-175

Open access under Creative Commons Attribution-Non Commercial-Share A like 4.0 International Licence

(CC-BY-SA) 
Uha Julaeha | Parent Storytelling Skill at Baitul Maqdis Cipta Edukasi

Tabel 8 Kemampuan Mengolah Kontak Mata

\begin{tabular}{lllllll}
\hline \multirow{2}{*}{ Mampu } & Pretest & \multicolumn{3}{c}{ Posttest } & \multicolumn{3}{c}{ Selisih } \\
& $\mathrm{f}$ & $\%$ & $\mathrm{f}$ & $\%$ & $\mathrm{~F}$ & $\%$ \\
\hline Ya & 26 & $72 \%$ & 34 & $94 \%$ & 8 & $24 \%$ \\
Tidak & 10 & $28 \%$ & 2 & $6 \%$ & & \\
Total & 36 & $100 \%$ & 36 & $100 \%$ & & \\
\hline
\end{tabular}

Berdasarkan tabel tersebut, diketahui bahwa responden yang memilih jawaban "ya" pada soal pretest, sebelum diberikan treatment pelatihan storytelling, berupa "anda dapat mengolah kontak mata ketika mendongeng" sebanyak 26 orang (72\%) dan yang memilih jawaban "tidak" sebanyak 10 orang (28\%). Sedangkan responden yang memilih jawaban "ya" pada soal posttest, setelah diberikan treatment pelatihan storytelling sebanyak 34 orang (94\%) dan yang memilih jawaban "tidak" sebanyak 2 orang $(6 \%)$.

Hal tersebut menunjukkan adanya peningkatan setelah diberikan treatment pelatihan storytelling. Dilihat dari ad anya peningkatan jumlah yang menyatakan "ya" dan berkurangnya jumlah responden yang menyatakan "tidak" setelah diberikan metode storytelling, yaitu sebanyak 8 orang $(24 \%)$.

Tabel 9 Kemampuan Mengolah Mimik Wajah

\begin{tabular}{lllllll}
\hline \multirow{2}{*}{ Mampu } & \multicolumn{2}{c}{ Pretest } & \multicolumn{2}{c}{ Posttest } & \multicolumn{2}{c}{ Selisih } \\
& $\mathrm{f}$ & $\%$ & $\mathrm{f}$ & $\%$ & $\mathrm{f}$ & $\%$ \\
\hline Ya & 15 & $42 \%$ & 31 & $86 \%$ & \multirow{2}{*}{16} & $45 \%$ \\
Tidak & 21 & $58 \%$ & 5 & $14 \%$ & & \\
Total & 36 & $100 \%$ & 36 & $100 \%$ & & \\
\hline
\end{tabular}

Berdasarkan tabel tersebut, diketahui bahwa responden yang memilih jawaban "ya" pada soal pretest, sebelum diberikan treatment pelatihan storytelling, berupa "anda dapat mengolah mimik wajah ketika mendongeng" sebanyak 15 orang (42\%) dan yang memilih jawaban "tidak" sebanyak 21 orang (58\%). Sedangkan responden yang memilih jawaban "ya" pada soal posttest, setelah diberikan treatment pelatihan storytelling sebanyak 31 orang (86\%) dan yang memilih jawaban "tidak" sebanyak 5 orang $(14 \%)$.

Hal tersebut menunjukkan adanya peningkatan setelah diberikan treatment pelatihan storytelling. Dilihat dari adanya peningkatan jumlah yang menyatakan "ya" dan berkurangnya jumlah responden yang menyatakan "tidak" setelah diberikan metode storytelling, yaitu sebanyak 16 orang $(45 \%)$.

Tabel 10 Kemampuan Mengolah Gerak Tubuh

\begin{tabular}{lllllll}
\hline \multirow{2}{*}{ Mampu } & Pretest & \multicolumn{3}{c}{ Posttest } & \multicolumn{3}{c}{ Selisih } \\
& $\mathrm{f}$ & $\%$ & $\mathrm{f}$ & $\%$ & $\mathrm{f}$ & $\%$ \\
\hline Ya & 19 & $53 \%$ & 31 & $86 \%$ & 12 & $33 \%$ \\
Tidak & 17 & $47 \%$ & 5 & $14 \%$ & & \\
Total & 36 & $100 \%$ & 36 & $100 \%$ & & \\
\hline
\end{tabular}

Berdasarkan tabel tersebut, diketahui bahwa responden yang memilih jawaban "ya" pada soal pretest, sebelum diberikan treatment pelatihan storytelling, berupa "anda dapat mengolah gerak tubuh ketika mend ongeng" sebanyak 19 orang (53\%) dan yang memilih jawaban "tidak" sebanyak 17 orang (47\%). Sedangkan responden yang memilih jawaban "ya" pada soal posttest, setelah diberikan treatment pelatihan storytelling sebanyak 31 orang (86\%) dan yang memilih jawaban "tidak" sebanyak 5 orang $(14 \%)$.

Hal tersebut menunjukkan adanya peningkatan setelah diberikan treatment pelatihan storytelling. Dilihat dari adanya peningkatan jumlah yang menyatakan "ya" dan berkurangnya jumlah

To cite this document:

Uha Julaeha, (2019), Parent Storytelling Skill at Baitul Maqdis Cipta Edukasi, Record

and Library Journal, 5(2), 160-175

Open access under Creative Commons Attribution-Non Commercial-Share A like 4.0 International Licence

(CC-BY-SA)

(c) (i) (2) 
responden yang menyatakan "tidak" setelah diberikan metode storytelling, yaitu sebanyak 12 orang $(33 \%)$.

Tabel 11 Kemampuan Mengolah Kelincahan Gerak

\begin{tabular}{|c|c|c|c|c|c|c|}
\hline \multirow{2}{*}{ Mampu } & \multicolumn{2}{|l|}{ Pretest } & \multicolumn{2}{|c|}{ Posttest } & \multicolumn{2}{|c|}{ Selisih } \\
\hline & f & $\%$ & f & $\%$ & f & $\%$ \\
\hline $\mathrm{Ya}$ & 13 & $36 \%$ & 29 & $81 \%$ & \multirow{3}{*}{16} & \multirow{3}{*}{$45 \%$} \\
\hline Tidak & 23 & $64 \%$ & 7 & $19 \%$ & & \\
\hline Total & 36 & $100 \%$ & 36 & $100 \%$ & & \\
\hline
\end{tabular}

Berdasarkan tabel tersebut, diketahui bahwa responden yang memilih jawaban "ya" pada soal pretest, sebelum diberikan treatment pelatihan storytelling, berupa "anda dapat mengolah kelincahan gerak ketika mendongeng" sebanyak 13 orang (36\%) dan yang memilih jawaban "tidak" sebanyak 23 orang (64\%). Sedangkan responden yang memilih jawaban "ya" pada soal posttest, setelah diberikan treatment pelatihan storytelling sebanyak 29 orang (81\%) dan yang memilih jawaban "tidak" sebanyak 7 orang (19\%).

Hal tersebut menunjukkan adanya peningkatan setelah diberikan treatment pelatihan storytelling. Dilihat dari adanya peningkatan jumlah yang menyatakan "ya" dan berkurangnya jumlah responden yang menyatakan "tidak" setelah diberikan metode storytelling, yaitu sebanyak 12 orang $(33 \%)$.

Tabel 12 Kemampuan Mengolah Suara

\begin{tabular}{|c|c|c|c|c|c|c|}
\hline \multirow{2}{*}{ Mampu } & \multicolumn{2}{|c|}{ Pretest } & \multicolumn{2}{|c|}{ Posttest } & \multicolumn{2}{|c|}{ Selisih } \\
\hline & f & $\%$ & f & $\%$ & $\mathrm{~F}$ & $\%$ \\
\hline $\mathrm{Ya}$ & 13 & $36 \%$ & 32 & $89 \%$ & \multirow{3}{*}{19} & \multirow{3}{*}{$53 \%$} \\
\hline Tidak & 23 & $64 \%$ & 4 & $11 \%$ & & \\
\hline Total & 36 & $100 \%$ & 36 & $100 \%$ & & \\
\hline
\end{tabular}

Berdasarkan tabel tersebut, diketahui bahwa responden yang memilih jawaban "ya" pada soal pretest, sebelum diberikan treatment pelatihan storytelling, berupa "anda dapat mengolah kelincahan gerak ketika mendongeng" sebanyak 13 orang (36\%) dan yang memilih jawaban "tidak" sebanyak 23 orang (64\%). Sedangkan responden yang memilih jawaban "ya" pada soal posttest, setelah diberikan treatment pelatihan storytelling sebanyak 32 orang $(89 \%)$ dan yang memilih jawaban "tidak" sebanyak 4 orang (11\%).

Hal tersebut menunjukkan adanya peningkatan setelah diberikan treatment pelatihan storytelling. Dilihat dari ad anya peningkatan jumlah yang menyatakan "ya" dan berkurangnya jumlah responden yang menyatakan "tidak" setelah diberikan metode storytelling, yaitu sebanyak 19 orang $(53 \%)$.

Tabel 13 Kemampuan Mengolah Alat Peraga

\begin{tabular}{|c|c|c|c|c|c|c|}
\hline \multirow{2}{*}{ Mampu } & \multicolumn{2}{|c|}{ Pretest } & \multicolumn{2}{|c|}{ Posttest } & \multicolumn{2}{|c|}{ Selisih } \\
\hline & f & $\%$ & f & $\%$ & f & $\%$ \\
\hline $\mathrm{Ya}$ & 19 & $53 \%$ & 29 & $80 \%$ & \multirow{3}{*}{10} & \multirow{3}{*}{$27 \%$} \\
\hline Tidak & 17 & $47 \%$ & 7 & $20 \%$ & & \\
\hline Total & 36 & $100 \%$ & 36 & $100 \%$ & & \\
\hline
\end{tabular}

Berdasarkan tabel di atas bahwa responden yang memilih jawaban "ya" pada soal pretest, sebelum diberikan treatment pelatihan storytelling, berupa "anda dapat mengolah alat peraga ketika mend ongeng" sebanyak 19 orang (53\%) dan yang memilih jawaban "tidak" sebanyak 17 orang (47\%). Sedangkan responden yang memilih jawaban "ya" pada soal posttest, setelah diberikan treatment pelatihan storytelling sebanyak 29 orang (80\%) dan yang memilih jawaban "tidak" sebanyak 7 orang $(20 \%)$.

Hal tersebut menunjukkan adanya peningkatan setelah diberikan treatment pelatihan To cite this document:

Uha Julaeha, (2019), Parent Storytelling Skill at Baitul Maqdis Cipta Edukasi, Record

and Library Journal, 5(2), 160-175

Open access under Creative Commons Attribution-Non Commercial-Share A like 4.0 International Licence

(CC-BY-SA)

(c) (i) (2) 
storytelling. Dilihat dari ad anya peningkatan jumlah yang menyatakan "ya" dan berkurangnya jumlah responden yang menyatakan "tidak" setelah diberikan metode storytelling, yaitu sebanyak 10 orang $(27 \%)$.

Tabel 14 Peningkatan Kemampuan Menuturkan Dongeng

\begin{tabular}{lll}
\hline \multirow{2}{*}{ Sub Kemampuan } & Selisih & \\
& $\mathrm{F}$ & $\%$ \\
\hline Mengolah Kontak Mata & 8 & $24 \%$ \\
Mengolah Mimi Wajah & 16 & $44 \%$ \\
Mengolah Gerak Tubuh & 12 & $33 \%$ \\
Mengolah Kelincahan & 16 & $45 \%$ \\
Mengolah Suara & 19 & $53 \%$ \\
Mengolah Alat Peraga & 10 & $27 \%$ \\
Peningkatan & 13 & $37 \%$ \\
\hline
\end{tabular}

Berdasarkan hasil dari keenam kuisioner tersebut dapat disimpulkan bahwa terdapat peningkatan kemampuan dalam menuturkan dongeng setelah diberikan treatment pelatihan mendongeng yaitu sebanyak 13 orang (38\%).

Tabel 15 Kemampuan Menyampaikan Pesan Tepat Waktu

\begin{tabular}{lllllll}
\hline \multirow{2}{*}{ Mampu } & Pretest & \multicolumn{3}{c}{ Posttest } & Selisih \\
& $\mathrm{f}$ & $\%$ & $\mathrm{f}$ & $\%$ & $\mathrm{~F}$ & $\%$ \\
\hline Ya & 17 & $47 \%$ & 33 & $92 \%$ & \multirow{2}{*}{16} & \multirow{2}{*}{$45 \%$} \\
Tidak & 19 & $53 \%$ & 3 & $8 \%$ & & \\
Total & 36 & $100 \%$ & 36 & $100 \%$ & & \\
\hline
\end{tabular}

Berdasarkan tabel tersebut, diketahui bahwa responden yang memilih jawaban "ya" pada soal pretest, sebelum diberikan treatment pelatihan storytelling, berupa "anda dapat mengetahui waktu yang tepat untuk menyampaikan pesan dibalik narasi dongeng" sebanyak 17 orang (47\%) dan yang memilih jawaban "tidak" sebanyak 19 orang (53\%). Sedangkan responden yang memilih jawaban "ya" pada soal posttest, setelah diberikan treatment pelatihan storytelling sebanyak 33 orang (92\%) dan yang memilih jawaban "tidak" sebanyak 3 orang (8\%).

Hal tersebut menunjukkan adanya peningkatan setelah diberikan treatment pelatihan storytelling. Dilihat dari adanya peningkatan jumlah yang menyatakan "ya" dan berkurangnya jumlah responden yang menyatakan "tidak" setelah diberikan metode storytelling, yaitu sebanyak 16 orang $(45 \%)$.

Tabel 16 Kemampuan Menyampaikan Pesan Moral

\begin{tabular}{|c|c|c|c|c|c|c|}
\hline \multirow{2}{*}{ Mampu } & \multicolumn{2}{|l|}{ Pretest } & \multicolumn{2}{|c|}{ Posttest } & \multicolumn{2}{|c|}{ Selisih } \\
\hline & $\mathrm{f}$ & $\%$ & $\mathrm{f}$ & $\%$ & $\mathrm{f}$ & $\%$ \\
\hline $\mathrm{Ya}$ & 23 & $64 \%$ & 34 & $94 \%$ & 11 & $30 \%$ \\
\hline Tidak & 13 & $36 \%$ & 2 & $6 \%$ & 11 & $30 \%$ \\
\hline Total & 36 & $100 \%$ & 36 & $100 \%$ & & \\
\hline
\end{tabular}

Berdasarkan tabel tersebut, diketahui bahwa responden yang memilih jawaban "ya" pada soal pretest, sebelum diberikan treatmen pelatihan storytelling, berupa "anda dapat menyampaikan pesan moral yang terdapat pada cerita dongeng" sebanyak 23 orang $(64 \%)$ dan yang memilih jawaban "tidak" sebanyak 13 orang (36\%). Sedangkan responden yang memilih jawaban "ya" pada soal posttest, setelah diberikan treatment pelatihan storytelling sebanyak 34 orang (94\%) dan yang memilih jawaban "tidak" sebanyak 2 orang $(6 \%)$.

Hal tersebut menunjukkan adanya peningkatan setelah diberikan treatment pelatihan storytelling. Dilihat dari ad anya peningkatan jumlah yang menyatakan "ya" dan berkurangnya jumlah 
responden yang menyatakan "tidak" setelah diberikan metode storytelling, yaitu sebanyak 11 orang $(30 \%)$.

Tabel 17 Peningkatan Kemampuan Menuturkan Pesan Dibalik Narasi

\begin{tabular}{lll}
\hline \multirow{2}{*}{ Sub Kemampuan } & $\begin{array}{l}\text { Selisih } \\
\mathrm{f}\end{array}$ & $\%$ \\
\hline Menyampaikan Pesan Tepat Waktu & 16 & $45 \%$ \\
Menyampaikan Pesan Moral & 11 & $30 \%$ \\
Peningkatan & 14 & $38 \%$ \\
\hline
\end{tabular}

Berdasarkan hasil dari kedua kuisioner tersebut dapat disimpulkan bahwa terdapat peningkatan kemampuan dalam menuturkan pesan dibalik narasi setelah diberikan treatment pelatihan mendongeng yaitu sebanyak 14 orang (38\%).

Negative Differences menyatakan banyaknya nilai 'variabel sesudah' dengan jumlah lebih kecil daripada 'variabel sebelum'. Sedangkan Positive Differrences menyatakan banyaknya nilai 'variabel sesudah' mempunyai jumlah yang lebih besar daripada 'variabel sebelum'. Sebaliknya, Ties menyatakan banyaknya nilai 'variabel sesudah' mempunyai jumlah yang sama besar nilainya dengan 'variabel sebelum'.

\section{Kemampuan Mendongeng Sebelum dan Sesudah Diberikan Pelatihan Storytelling}

Tabel 18 Hasil Keseluruhan Uji Tanda Kemampuan Mendongeng

\begin{tabular}{llc}
\hline & $\mathrm{N}$ \\
\hline Posttest - Pretest & Negative Differences $^{a}$ & 2 \\
& Positive Differences $^{b}$ & 26 \\
& Ties $^{c}$ & 8 \\
& Total & 36 \\
\hline
\end{tabular}

aPosttest $<$ Pretest
bPosttest $>$ Pretest
${ }^{\text {cPosttest }}=$ Pretest

\begin{tabular}{lc}
\multicolumn{2}{c}{ Test Statistics $^{a}$} \\
\hline Posttest - Pretest \\
\hline Z & $-4,347$ \\
Asymp. Sig. (2-tailed) &, 000 \\
\hline
\end{tabular}

${ }^{\text {a Sign Test }}$

Sumber: Kuisioner Pelatihan Storytelling

Berdasarkan hasil pengujian statistik menggunakan rumus uji tanda dengan derajat kepercayaan $95 \%$, diperoleh nilai p-value atau asymp sig $(0,000)<$ alpha $(0,05)$ dan hasil Zhitung $(-4,347$ senilai dengan 4,347) lebih besar dari Ztabel $(0,999997)$ maka dinyatakan signifikan atau $\mathrm{H}_{0}$ ditolak dan $\mathrm{H}_{1}$ diterima. Hal ini berarti terdapat hubungan yang signifikan pada kemampuan mendongeng peserta antara sebelum dan sesudah pelatihan storytelling.

Kemudian peneliti memperinci kemampuan mendongeng pada peserta pelatihan storytelling berdasarkan variabel indikator sebagai berikut:

\section{Kemampuan Peserta Dalam Memahami dan Memilih Bahan Cerita Sebelum dan Sesudah Diberikan Pelatihan Storytelling}

Tabel 19 Hasil Uji Tanda Kemampuan Memahami dan Memilih Bahan Cerita (K1)

To cite this document:

Uha Julaeha, (2019), Parent Storytelling Skill at Baitul Maqdis Cipta Edukasi, Record

and Library Journal, 5(2), 160-175

Open access under Creative Commons Attribution-Non Commercial-Share A like 4.0 International Licence

(CC-BY-SA)

$$
\text { (c) (1) (2) }
$$




\begin{tabular}{llc}
\hline & & $\mathrm{N}$ \\
\hline K1 Posttest - K1 Pretest & Negative Differences $^{a}$ & 1 \\
& Positive Differences $^{b}$ & 12 \\
& Ties $^{c}$ & 23 \\
& Total & 36 \\
\hline
\end{tabular}

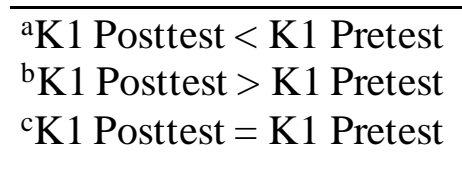

\begin{tabular}{lc}
\multicolumn{2}{c}{ Test Statistics $^{\mathbf{a}}$} \\
\hline \multicolumn{2}{c}{ K1 Posttest - K1 Pretest } \\
\hline$Z$ & $-2,774$ \\
Asymp. Sig. (2-tailed) &, 003 \\
\hline
\end{tabular}

asign Test

Sumber: Kuisioner Pelatihan Storytelling

Berdasarkan hasil pengujian statistik menggunakan rumus uji tanda dengan derajat kepercayaan $95 \%$, diperoleh nilai p-value atau asymp sig $(0,003)$ lebih kecil dari alpha $(0,05)$ dan hasil Zhitung (2,774 senilai dengan 2,774) lebih besar dari $\mathrm{Z}_{\text {tabel }}(0,997197)$ maka dinyatakan signifikan atau $\mathrm{H}_{0}$ ditolak dan $\mathrm{H}_{1}$ diterima. Hal ini berarti terdapat hubungan yang signifikan pada kemampuan memahami dan memilih bahan cerita antara sebelum dan sesudah pelatihan storytelling. Yaitu terdapat perbedaan pada penambahan pengetahuan dan kemampuan memahami dan memilih bahan cerita setelah menerima treatment.

\section{Kemampuan Peserta Dalam Menuturkan Dongeng Sebelum dan Sesudah Diberikan Pelatihan Storytelling}

Tabel 20 Hasil Uji Tanda Kemampuan Menuturkan Dongeng (K2)

\begin{tabular}{clc}
\hline & & $\mathrm{N}$ \\
\hline K2 Posttest - K2 Pretest & Negative Differences & \\
& Positive & 1 \\
& Differences $^{\mathrm{b}}$ & 26 \\
& Ties $^{\mathrm{c}}$ & 9 \\
& Total & 36 \\
\hline
\end{tabular}

${ }^{\mathrm{a} K} 2$ Posttest $<$ K2 Pretest
${ }^{\mathrm{b}} \mathrm{K} 2$ Posttest $>$ K2 Pretest
${ }^{\mathrm{c}}$ K2 Posttest $=$ K2 Pretest

Test Statistics ${ }^{\mathrm{a}}$

\begin{tabular}{lc}
\hline & K2 Posttest - K2 Pretest \\
$Z$ & $-4,619$ \\
Asymp. Sig. (2-tailed) &, 000 \\
\hline
\end{tabular}

${ }^{\text {aSign Test }}$

Sumber: Kuisioner Pelatihan Storytelling

Berdasarkan hasil pengujian statistik menggunakan rumus uji tanda dengan derajat kepercayaan $95 \%$, diperoleh nilai p-value atau asymp sig $(0,000)$ lebih kecil dari alpha $(0,05)$ dan hasil zhitung (4,619 senilai dengan 4,619) lebih besar dari ztabel $(0,999997)$ maka dinyatakan signifikan atau $\mathrm{H}_{0}$

To cite this document:

Uha Julaeha, (2019), Parent Storytelling Skill at Baitul Maqdis Cipta Edukasi, Record

and Library Journal, 5(2), 160-175

Open access under Creative Commons Attribution-Non Commercial-Share A like 4.0 International Licence

(CC-BY-SA)

(c) (i) (2) 
ditolak dan $\mathrm{H}_{1}$ diterima. Hal ini berarti terdapat hubungan yang signifikan pada kemampuan menuturkan dongeng antara sebelum dan sesudah pelatihan storytelling. Yaitu terdapat perbedaan pada penambahan pengetahuan dan kemampuan menuturkan dongeng setelah menerima treatment.

\section{Kemampuan Peserta Dalam Menuturkan Pesan Dibalik Narasi Sebelum dan Sesudah Diberikan Pelatihan Storytelling}

Tabel 21 Hasil Uji Tanda Kemampuan Menuturkan Pesan (K3)

\begin{tabular}{|c|c|c|}
\hline & & $\mathrm{N}$ \\
\hline \multirow[t]{4}{*}{ K3 Posttest - K3 Pratest } & Negative Differences ${ }^{a}$ & 1 \\
\hline & Positive Differences ${ }^{b}$ & 15 \\
\hline & $\operatorname{Ties}^{\mathrm{c}}$ & 20 \\
\hline & Total & 36 \\
\hline \multirow{3}{*}{\multicolumn{3}{|c|}{$\begin{array}{l}{ }^{\mathrm{a} K 3} \text { Posttest }<\text { K3 Pratest } \\
{ }^{\mathrm{b}} \mathrm{K} 3 \text { Posttest }>\text { K3 Pratest } \\
{ }^{\mathrm{c}} \text { K3 Posttest }=\text { K3 Pratest }\end{array}$}} \\
\hline & & \\
\hline & & \\
\hline \multicolumn{3}{|c|}{ Test Statistics $^{\mathrm{a}}$} \\
\hline & \multicolumn{2}{|c|}{ K3 Posttest - K3 Pretest } \\
\hline $\mathrm{Z}$ & \multicolumn{2}{|c|}{$-3,25$} \\
\hline Asymp. Sig. (2-tailed) & ,001 & \\
\hline
\end{tabular}

Berdasarkan hasil pengujian statistik menggunakan rumus uji tanda dengan derajat kepercayaan 95\%, diperoleh nilai p-value atau asymp sig $(0,001)$ lebih kecil dari alpha $(0,05)$ dan hasil Zhitung ($3,25$ senilai dengan 3,25$)$ lebih besar dari $\mathrm{Z}_{\text {tabel }}(0,999423)$ maka dinyatakan signifikan atau $\mathrm{H}_{0}$ ditolak dan $\mathrm{H}_{1}$ diterima. Hal ini berarti terdapat hubungan yang signifikan pada kemampuan menuturkan pesan dibalik narasi dongeng antara sebelum dan sesudah pelatihan storytelling. Yaitu terdapat perbedaan pada penambahan pengetahuan dan kemampuan menuturkan pesan dibalik narasi dongeng setelah menerima treatment.

Pelatihan storytelling merupakan proses pembelajaran edukatif untuk individu atau sekelompok individu melalui suatu bentuk karya sastra yang berisi pesan moral mendongeng dengan metode bertutur (tanpa teks) yang diselenggarakan oleh organisasi (instansi pemerintah / lembaga swadaya masyarakat / perusahaan) untuk memperoleh dan meningkatkan keterampilan dengan menggunakan prosedur sistematik dan terorganisir yang lebih mengutamakan praktik daripada teori dan dilakukan dalam waktu relatif singkat.

Menurut Kurniawan (2013) dan Bunanta (2009) dalam Yulia (2017), tolak ukur baik buruknya mendongeng ditentukan oleh tiga aspek, yaitu: kesesuaian dengan perkembangan anak (memperhatikan plot cerita, unsur imajinasi, dan bahasa sesuai usia anak); sifatnya menghibur dan menyenangkan (memperhatikan kontak mata, mimik wajah, gerak tubuh, kelincahan gerakan, suara, dan alat peraga); Serta nilai-nilai yang memberikan pemahaman dan pendidikan pada anak (mengetahui waktu yang sesuai untuk menuturkan hikmah dibalik cerita sesudah dongeng berlangsung).

Berdasarkan hasil pretest-posttest yang telah dibagikan sebelum dan setelah pelatihan storytelling, terdapat perbedaan kemampuan mendongeng pada orang tua sebelum dan setelah pelatihan storytelling di Baitul Maqdis Cipta Edukasi. Sebanyak 9 dari 36 peserta mengalami peningkatan pada kemampuan memahami dan memilih bahan cerita sesuai dengan usia perkembangan anak (K1) berupa mencari bahan cerita, menyeleksi bahan cerita, dan menentukan bahan cerita; kemampuan dalam menuturkan dongeng (K2) berupa pengolahan kontak mata, mimik To cite this document:

Uha Julaeha, (2019), Parent Storytelling Skill at Baitul Maqdis Cipta Edukasi, Record and Library Journal, 5(2), 160-175

Open access under Creative Commons Attribution-Non Commercial-Share A like 4.0 International Licence (CC-BY-SA) 
wajah, gerak tubuh (kelincahan gerak), mengolah suara, dan mengolah alat peraga juga mengalami peningkatan sebanyak 14 dari 36 peserta; serta sebanyak 13 dari 36 mengalami peningkatan pada kemampuan dalam menuturkan pesan dibalik narasi dongeng berupa menyampaikan pesan tepat waktu dan menyampaikan pesan moral. Meskipun kemampuan dalam menuturkan dongeng mengalami peningkatan yang paling signifikan, namun setelah diberikan treatment jumlah peserta yang memiliki kemampuan tersebut paling sedikit, jika dibandingkan dengan jumlah peserta pada kemampuan lain seperti memahami dan memilih bahan cerita, serta menuturkan pesan dibalik narasi dongeng. Hal ini disebabkan karena kemampuan dalam menuturkan dongeng membutuhkan konstruksi pengetahuan yang lebih daripada kemampuan lain.

Piaget dalam Wardhana (2010) menjelaskan bahwa mengonstruksi -pengetahuan- dilakukan melalui proses asimilasi dan akomodasi terhadap skema yang ada. Skema terbentuk melalui proses pengalaman, sedangkan asimilasi adalah proses perubahan skema. Dalam pelatihan ini, skema disimulasikan dengan bentuk pelatihan storytelling dan asimilasi berlangsung ketika sesi praktik mendongeng. Pelatihan akan berhasil jika individu belum pernah mendapatkan pelatihan yang sama atau serupa sebelumnya. Selain itu Wedan (2016) menjelaskan bahwa konstruktivisme membuat manusia lebih paham bagaimana menyelesaikan masalah, mencari ide, dan membuat keputusan ketika mereka terlibat langsung dalam pengetahuan baru. Peserta dalam pelatihan storytelling tidak akan mampu memasuki cara mendongeng yang dipraktikkan pelatih jika tidak ada keinginan atau urgensi diri dalam mempelajari storytelling untuk diaplikasikan. Pada pelatihan ini, keseluruhan peserta memiliki ketertarikan untuk belajar storytelling. Proses belajar dianggap berhasil jika individu memahami lingkungannya dan dirinya sendiri.

Hasil pretest-posttest juga menunjukkan terdapat 8 orang yang menjawab "mampu" terkait kemampuan memilih bahan cerita dongeng, kemampuan dalam menuturkan dongeng, dan kemampuan dalam menuturkan pesan di balik narasi pada 11 soal dengan pertanyaan terkait: mencari bahan cerita dongeng; menyeleksi bahan cerita dongeng; menentukan bahan cerita dongeng; mengolah kontak mata saat mend ongeng; mengolah mimik wajah saat mendongeng; mengolah gerak tubuh saat mendongeng; mengolah kelincahan gerak saat mendongeng; mengolah suara saat mendongeng; mengolah alat peraga yang tersedia saat mendongeng; waktu yang tepat saat menyampaikan pesan dibalik narasi dongeng; dan menyampaikan pesan moral yang terdapat pada cerita dongeng. Artinya, mereka memiliki kemampuan dalam mendongeng tanpa diberikan pelatihan. Delapan orang tersebut diantaranya, 5 orang sudah mengikuti pelatihan dongeng sebelumnya dan 3 orang yang belum mengikuti pelatihan sebelumnya. Diantara 3 orang yang belum mengikuti pelatihan sebelumnya terdapat 2 orang berprofesi sebagai guru dan 1 orang berstatus ibu rumah tangga. Berdasarkan hasil wawancara ketiga peserta yang menjawab "mampu" pada setiap soal pretestposttest namun belum mengikuti pelatihan dongeng sebelumnya, mereka sering berinteraksi dengan buku cerita atau sering melihat orang mendongeng. Sehingga mereka tidak asing dengan aktivitas mendongeng.

Selain itu, data responden menunjukkan terdapat 11 orang yang pernah mengikuti pelatihan mendongeng sebelumnya. Dimana 5 diantaranya menjawab "mampu" pada tiap soal yang diberikan seperti pertanyaan di atas. Sedangkan 6 orang sisanya masih mengalami kesulitan pada kemampuan dalam menuturkan dongeng. Berdasarkan hasil wawancara, beberapa dari mereka masih mengalami kesulitan dengan kemampuan dalam menuturkan dongeng berupa pengolahan suara dan alat peraga. Mereka mengalami peningkatan kemampuan menuturkan dongeng setelah diberikan pelatihan storytelling dari Baitul Maqdis Cipta Edukasi ini. Hal ini dibuktikan dengan menjawab "mampu" pada soal posttest yang diberikan. Menurut Wicaksana (2010) pelatihan akan tepat apabila terjadi kesenjangan kinerja (lack of performance) yang penting. Kesenjangan tersebut disebabkan oleh kesenjangan pengetahuan atau skill (kemampuan). Hal ini dikarenakan individu memiliki potensi untuk menyerap atau mempraktikan pelatihan yang didapat.

Pada sesi praktik pelatihan storytelling di Baitul Maqdis Cipta Eduksi, peserta dibentuk kelompok untuk menentukan segmentasi cerita yang akan diperagakan sampai dengan menuturkan

To cite this document:

Uha Julaeha, (2019), Parent Storytelling Skill at Baitul Maqdis Cipta Edukasi, Record

and Library Journal, 5(2), 160-175

Open access under Creative Commons Attribution-Non Commercial-Share A like 4.0 International Licence

(CC-BY-SA)

$$
\text { (c) (i) (2) }
$$


pesan dibalik narasi dongeng yang mereka buat. Menurut Mezirow (1981) dalam Malik (2011) bahwa belajar dalam kelompok pada umumnya merupakan alat yang paling efektif untuk menimbulkan perubahan dalam sikap dan perilaku individu. Berkelompok juga memungkinkan individu untuk saling bertukar pengalaman.

Berdasarkan hasil observasi pelatihan storytelling, ada perbedaan cara mendongeng antara perempuan dengan laki-laki. Perempuan cenderung mengekspresikan intonasi suara, gerak tubuh, mimik muka, dan atraktif. Sedangkan laki-laki cenderung kaku dan monoton. Hal ini disebabkan karena mayoritas peserta pelatihan storytelling adalah perempuan yang sudah menikah dan memiliki anak. Perempuan terbiasa menggunakan bodylanguage saat berinteraksi dengan anak mereka.

Menurut Verman dalam Pratiwi (2017), otak perempuan lebih bisa mengaitkan memori dan keadaan sosial, ini yang menjadi alasan perempuan lebih sering mengandalkan perasaan. Sedangkan laki-laki memiliki kemampuan yang lebih kuat pada motorik seperti aktivitas fisik. Menurut Amen dalam Pratiwi (2017), adanya perbedaan respon antara perempuan dan laki-laki terjadi karena perempuan memiliki verbal center pada kedua bagian otaknya, sedangkan laki-laki hanya memiliki verbal center pada otak bagian kiri sehingga laki-laki tidak memiliki 'koneksi' yang baik tentang halhal yang melibatkan perasaan, emosi, atau curahan hati.

\section{Simpulan}

Berdasarkan hasil pengujian statistik menggunakan rumus uji tandadengan derajat kepercayaan $95 \%$, diperoleh nilai p-value atau asymp sig $(0,000)<$ alpha $(0,05)$ dan hasil Zhitung $-4,347$ (senilai dengan 4,347) lebih besar dari $\mathrm{Z}_{\text {tabel }} 0,999997$ maka dinyatakan signifikan atau $\mathrm{H}_{0}$ ditolak dan $\mathrm{H}_{1}$ diterima. Hal ini berarti terdapat hubungan yang signifikan pada kemampuan mendongeng peserta antara sebelum dan sesudah pelatihan storytelling. Yaitu terdapat perbedaan pada penambahan pengetahuan responden tentang kemampuan mendongeng setelah menerima treatment berupa pelatihan storytelling. Kemampuan mendongeng peserta dalam pelatihan ini mengalami peningkatan. Hanya saja, kemampuan menuturkan dongeng membutuhkan lebih dari satu kali sesi praktik untuk mendapatkan hasil maksimal. Peserta pelatihan yang terdiri dari orang dewasa mampu menyerap materi dan dapat mengimitasi apa yang diajarkan pelatih, kemudian dipraktikan kembali dengan baik sesuai kebutuhan mereka. Dengan demikian, hasil penelitian ini dapat menjadi salah satu alternatif untuk meningkatkan kemampuan orang dewasa dalam mendongeng. Serta dapat dikembangkan untuk menstimulasi pembelajaran dan pendidikan lainnya seperti literasi informasi, minat baca, knowledge sharing, dan lainnya.

\section{Ucapan Terima Kasih}

Penulis mengucapkan terimakasih banyak untuk semua pihak yang telah bersedia terlibat dalam penelitian ini. Khususnya keluarga yang telah mendukung penulis secara materiil dan moral, kepada para peserta pelatihan storytelling, kepada sivitas akademik Universitas Padjadjaran terutama Program Studi Ilmu Perpustakaan dan Informasi, Lembaga Edukasi Baitul Maqdis Cipta Edukasi, serta kepada pihak-pihak yang tidak bisa disebutkan satu persatu.

\section{Referensi}

Agustin, L. N. (2017). Pengaruh Media Pop-Up Book Untuk Meningkatkan Kosakata Bahasa Inggris Anak Usia Dini. Bandung: Universitas Pendidikan Indonesia.

Ayuni, R. D., Siswati, Rusmawati, D. (2013). Pengaruh storytelling terhadap perilaku empati anak. Jurnal Psikologi Undip, 12(2), 81-121. DOI: https://doi.org/10.14710/jpu.12.2.121-130

Christensen, L. B. (2007). Experimental Methodology: Tenth Edition. Boston: Pearson Education. Frude, N. and Killick, S. (2011). Family storytelling and the attachment relationship. Psychodynamic Practice, 17(4), 441-455, DOI: 10.1080/14753634.2011.609025

Julaeha, U., \& Faradilla, A. (2016). Fairytale Roles in Family Communication as Effort to Encourage Early Childhood Development: Literature Study. In The 7th Indonesia-Japan Joint Scientific

To cite this document:

Uha Julaeha, (2019), Parent Storytelling Skill at Baitul Maqdis Cipta Edukasi, Record

and Library Journal, 5(2), 160-175

Open access under Creative Commons Attribution-Non Commercial-Share A like 4.0 International Licence

(CC-BY-SA) (c) (1) (2) 
Symposium (pp. 86-93). Chiba: Chiba University.

Kurniawan, H. (2013). Keajaiban Mendongeng: Memahami, Memilih, dan Menyajikan Dongeng Berkualitas untuk Perkembangan Moral Anak. Jakarta: Bhuana Ilmu Populer.

Malik, H. (2011). Teori Belajar Andragogi dan Penerapannya. Retrieved January 6, 2019, from https://www.kompasiana.com/unik/55008878a33311ef6f511659/teori-belajar-andragogi-danpenerapannya

Malo, E. and Bullard, J. (2010). Storytelling and the Emergent Reader. ERIC, 1-16. Retrieved from https://files.eric.ed.gov/fulltext/ED448464.pdf

Oduolowu, E., \& Oluwakemi, A. E. (2014). Effect of storytelling on listening skills of primary one pupil in Ibadan North local government area of Oyo state, Nigeria. International journal of humanities and social science, 4(9), 100-107.

OECD. (2015). PISA 2015: PISA Result In Focus. Retrieved from https://www.oecd.org/pisa/pisa2015-results-in-focus.pdf

OEDC. (2012). PISA 2012 Result In Focus. Retrieved from Padila, Agusramon dan Yera. (2019). Terapi story telling dan menonton animasi kartun terhadap ansietas. Journal of Telenursing(JOTING), 1(1), 51-66. DOI:DOI: https://doi.org/10.31539/joting.v1i1.51451

Pratiwi, R. (2017). Perbedaan Cara Berpikir Perempuan dan Laki-laki. Retrieved January 12, 2019, from https://hellosehat.com/hidup-sehat/fakta-unik/perbedaan-cara-berpikir-perempuan-d anlaki-laki/

Prijana, Winoto, Y., \& Yanto, A. (2016). Metode Penelitian Kuantitatif. Bandung: Unpad Press.

https://www.oecd.org/pisa/keyfindings/pisa-2012-results-overview.pdf

Raharjo, S. B. (2012). Evaluasi Trend Kualitas Pendidikan di Indonesia. Jurnal Penelitian Dan Evaluasi Pendidikan, 511-532.

Rihandoyo. (2009). Alat Uji Hipotesis Penelitian Sosial Non Parametrik. [Available from http://eprints.undip.ac.id/5079/1/Statistik_non_parametrik_dengan_SPSS.pdf]

Sundari, H. (2016). Pengaruh input bahasa orang tua terhadap kompleksitas bahasa anak: studi kasus pada anak usia 5 tahun melalui interactive shared reading. Jurnal Pendidikan Bahasa dan Sastra, (16)1, 110-121. DOI:http://dx.doi.org/10.17509/bs_jpbsp.v16i1.3067

Wardhana, Y. (2010). Teori Belajar dan mengajar. Bandung: PT Pribumi Mekar.

Wardiah, D. (2017). Peran storytelling dalam meningkatkan kemampuan menulis, minat membaca dan kecerdasan emosional siswa. Wahana Didaktika, (15)2, 42-56. DOI: http://dx.doi.org/10.31851/wahanadidaktika.v15i2.1236

Wedan, M. (2016). Teori Belajar Konstruktivisme. [Available from http://silabus.org/teori-belajarkonstruktivisme/]

Wicaksana, S. (2010). Training For Trainers Module. [Available from https://www.slideshare.net/wicaksana/training-for-trainers-module]

Yulia. (2017). Meningkatkan Kemampuan Berkomunikasi Verbal Anak Melalui Mendongeng. Bandung: Universitas Pendidikan Indonesia.

To cite this document:

Uha Julaeha, (2019), Parent Storytelling Skill at Baitul Maqdis Cipta Edukasi, Record

and Library Journal, 5(2), 160-175

Open access under Creative Commons Attribution-Non Commercial-Share A like 4.0 International Licence

(CC-BY-SA)

$$
\text { (c) (1) (2) }
$$

